\title{
Research of the Aerosol Optical and Microphysical Characteristics of the Atmosphere over the Black Sea Region by the FIRMS System during the Forest Fires in 2018-2019
}

\author{
D. V. Kalinskaya1, *, A. S. Papkova1 , D. M. Kabanov² \\ ${ }^{1}$ Marine Hydrophysical Institute of RAS, Sevastopol, Russian Federation \\ ${ }^{2}$ Zuev Institute of Atmospheric Optics of the Siberian Branch of Russian Academy of Sciences, \\ Tomsk, Russian Federation \\ * kalinskaya_d_v@mail.ru
}

Purpose. The Black Sea region where the forest fires were recorded by the FIRMS system, as well as the atmosphere above it, namely the fire-induced variation of the atmospheric aerosol basic optical characteristics, were the main objects of the investigation. The study is aimed at examining the fires in the Black Sea region in 2018-2019 for assessing correlation between these events and variability of the basic optical characteristics over the Black Sea.

Methods and Results. Based on the FIRMS system data, variations of intensity of the fire-induced radiation were studied. The results of statistical processing of the MODIS and VIIRS satellite data on the fires in 2018-2019 were represented. For the dates when the fire numbers were the highest in the Black Sea region, the basic optical and microphysical characteristics of the atmospheric aerosol were analyzed due to the SPM and AERONET data. The dates when the fire intensity was particularly high (based on the MODIS and VIIRS data) were analyzed and compared with the dates when the anomalous values of the atmospheric aerosol optical characteristics were recorded over the region under study.

Conclusions. For the fire events in the Black Sea region revealed due to the MODIS and VIIRS data, complex analysis of the air mass transfer was performed by the model HYSPLIT, and the aerosol was typed by the CALIPSO algorithm. On June 22, 2019 the most intense fires were recorded. According to the aerosol typing by the CALIPSO algorithm, on this day the predominant aerosol types were the contaminated dust and smoke. Using the MODIS and VIIRS data, investigation of possible source of the aerosol transfer on this date showed that the area of intense inflammationn and smoke was located to the northeast from the Black Sea region. Since the satellite-derived data on this day showed no dust transfer either from the Sahara or the Syria deserts, it is possible to conclude that increase of the values of aerosol optical depth AOD (500) was conditioned by transfer of the aerosol resulted from biomass burning from the north to the Black Sea region.

Keywords: EOSDIS, MODIS, VIIRS, SPM, AERONET, CALIPSO, 7-day back trajectories, Black Sea, HYSPLIT, smoke, soot, smog, absorbing aerosol, thermal anomalies, optical thickness of aerosol.

Acknowledgments: the investigation was carried out at the support of the RFBR grant No. 19-05-50023 and the state task theme No. 0827-2019-0002. The authors are grateful to S. M. Sakerin for providing the SPM photometer and the corresponding software.

For citation: Kalinskaya, D.V., Papkova, A.S. and Kabanov, D.M., 2020. Research of the Aerosol Optical and Microphysical Characteristics of the Atmosphere over the Black Sea Region by the FIRMS System during the Forest Fires in 2018-2019. Physical Oceanography, [e-journal] 27(5), pp. 514-524. doi:10.22449/1573-160X-2020-5-514-524

DOI: $10.22449 / 1573-160 X-2020-5-514-524$

(C) D. V. Kalinskaya, A. S. Papkova, D. M. Kabanov, 2020

(C) Physical Oceanography, 2020

\section{Introduction}

Fires play an important role in the formation of the local, regional and global variability of the atmosphere properties. This manifests itself, for example, in 
the release of greenhouse gases and aerosols into the atmosphere. Emissions of aerosol into the atmosphere formed as a result of forest fires can have a significant impact on the microphysical and optical characteristics of clouds, and, consequently, on the processes of precipitation and, as a result, on the weather of the whole region [1; 2, p. 215].

Fires make significant changes in the natural hydrophysical and ecological as well as biogeochemical cycles of elements. An increase in the scale of carboncontaining emissions causes ambiguous changes in the state of climatically active components of the atmospheric layer. These changes, in particular, include deformations of the micro- and macrostructure of cloud fields caused by active penetration of smoke aerosols into the atmosphere. Changes in the reflectivity of the underlying surface lead to difficultly predictable variations in radiation forcing [1, p. 126; 3, p. 247; 4].

Atmospheric aerosol and its constituent soot aerosol are radiation-active components of the atmosphere that affect climate change. In this regard, the study of sources of soot-containing aerosol of natural and anthropogenic nature, such as, for example, forest fires and city smog, is of considerable interest [1; 3, p. 247]. Soot is a byproduct of combustion and has a significant effect on the atmosphere, settling on low-lying clouds and trapping the Earth's heat. Estimates of the variability of relative soot content in atmospheric aerosol are important for the modernization of both empirical aerosol models and climatic estimates [3, 5]. In addition, due to air currents, soot moves over long distances and settles on any underlying surface, reducing its reflectivity, which can cause, for example, additional snow melting and water evaporation [6].

The complex impact of forest fires on atmospheric characteristics makes it difficult to assess the true scale of damage to the studied region. In this regard, the creation of modern interdisciplinary fire research methods is a fundamental task in the study and forecasting of atmospheric processes.

\section{Devices and materials}

EOSDIS (Earth Observing System (EOS) Data and Information System) is an international distributed system of space data bases, which was created and operates as part of CINTEX (Catalog Interoperability Experiment) pilot project for the exchange of catalogs. NASA EOSDIS information system is the main structureforming part of CINTEX. At present, this system includes 15 centers for storing and processing space data: 9 from the USA and one each from Australia, Germany, Israel, Canada, Russia and Japan. A feature of EOSDIS data system and, accordingly, CINTEX is that the user searches for data simultaneously in all data centers included in system ${ }^{1}$. EOSDIS provides all the services required for the execution of the EOS program, namely: data collection and storage, their processing, provision of means of remote access to reference information data catalogs [7, p. 241]. One of the EOS program features is the possibility to periodically structure the raw data archive using updated calibration and geolocation information [8].

${ }^{1}$ NASA, 2020. Earth Observing System Data and Information System (EOSDIS). [online] Available at: https://earthdata.nasa.gov/eosdis [Accessed: 06 August 2020]. 
The data array of MODIS spectral radiometer, namely, the data on thermal anomalies, or active fires, is one of the EOSDIS products [8]. Thermal anomalies are the first remotely detected objects with a resolution of $\sim 1 \mathrm{~km}$, which could be analyzed in a comparative relation with the smoke data obtained from onboard and ground sensors of a fire hazard. Until 2003, the forest fire monitoring system was based on the data from NOAA meteorological satellites and AVHRR high-resolution radiometers. Both satellite data sets contained information about the same territory, updated several times a day. The emergence of new space systems (TERRA/AQUA) based on MODIS made it possible to expand the capabilities of remote means and methods for monitoring the forest fires. Since 2003, MODIS module for primary and thematic data processing has been put into operation to create derivative products - thermal anomalies ${ }^{2}$. The data on MODIS fires have been used to solve a wide range of scientific problems regarding the impact of aerosol generated as a result of biomass burning on the Earth's climate [9-10], as well as numerous tasks of operational monitoring and remote sensing [11, 12].

The data provided by FIRMS (Fire Information for Resource Management System), which is a part of EOS (LANCE), are analyzed in the paper. For the analysis of thermal anomalies over the Black Sea, this fire information system, within 3 hours after the satellites pass over the study area, provides a file containing the coordinates of fires and information about their intensity obtained by VIIRS [13] and MODIS [14]. VIIRS is a two-band radiometer operating in the UV, IR and visible range $(0.45-12 \mu \mathrm{m})$.

The main parameter of the temperature anomaly (fire) intensity is the radiation power of fire (Fire Radiative Power, FRP). FRP defines the amount of thermal energy released per unit of time during the burning of vegetation and is measured in MW. In [15], the method for calculating the FRP index, which provided the estimation of the integral radiation power of heat radiation from a thermally active zone, was used.

On the basis of the technique of processing images in the infra-red range (on $4 \mu \mathrm{m}$ channel) according to MODIS and VIIRS data, variations in the radiation power from fires are investigated. The images of thermally active areas (thermal anomalies) located near the Black Sea region were processed using satellite data for the period 2018-2019. Each fire record in the database is a set of coordinates of the identified thermally active zones. For each site designated as a thermally active zone, the FRP index was calculated and statistical data on the localization and intensity of forest fires were obtained [3].

For determining the aerosol type over the region under study the CALIPSO satellite data were analyzed.

CALIPSO (Cloud-Aerosol Lidar and Infrared Pathfinder Satellite Observation) is a US-French research satellite launched as part of NASA EOS (Earth Observing System) program and designed to study the cloud cover of the Earth.

${ }^{2}$ Ershov, D.V., Korovin, G.N., Shulyak, P.P., Dvorkina, N.B., Kovganko, K.A., Petrov, P.V., Lupyan, E.A., Mazurov, A.A. and Proshin, A.A. [et al.], 2004. Russian Remote Monitoring System for Forest Fires. ArcReview, (4). [online] Available at: https://arcreview.esricis.ru/2004/10/13/wildfire-monitoring-russia/ [Accessed: 06 August 2020]. 
The main goal of CALIPSO is to carry out global measurements of aerosols and clouds. Such measurements are necessary for studying the degree of aerosols and clouds impact on the climate system, as well as for refining the forecast of long-term and seasonal interannual climate changes. CALIPSO is paired with the US-based CLOUDSAT (Cloud Satellite) system, $94 \mathrm{GHz}$ nadir-directed radar that measures the cloud backscatter as a function of distance.

The main measuring instrument of CALIPSO is a three-channel radiometer (operating wavelengths of the channels are $8.65 \mu \mathrm{m}, 10.6 \mu \mathrm{m}$ and $12.05 \mu \mathrm{m}$ ). Since the system is a lidar, it can be used for reconstructing the vertical structure of the atmosphere. Unlike the sunlight, the "green beam" (523 nm) of CALIPSO is fully polarized in one direction. Atmospheric scattering alters the incident polarization, and measuring the degree of depolarization provides a wealth of information about the nature of particles, especially their geometry. The preferred type of aerosol depends on the location of the measurement, on the value of the integrated backscattering coefficient and the depolarization coefficient of the particles [16]. Aerosol typing used by CALIPSO is derived from AERONET cluster analysis. The following types of aerosols are distinguished: smoke (aerosol formed from the biomass combustion), dust, contaminated dust (mixtures of dust and smoke), contaminated continental and pure continental aerosols [16-18]. Each type of aerosol is characterized by a set of lidar ratios at wavelengths of 532 and $1064 \mathrm{~nm}$. These ratios were calculated from typical distributions of particle sizes and complex refractive indices taken from the AERONET measurement database [19].

To determine the source of the aerosol generated from the biomass combustion, the reverse trajectories of air mass transfer were analyzed using the HYSPLIT model. HYSPLIT (Hybrid Single-Particle Lagrangian Integrated Trajectory model) is a system for calculating airflow trajectories, as well as complex transport, dispersion, chemical transformation and precipitation modeling. This model provides backward trajectory analysis to determine the origin of air masses and establish source - receptor relationships. HYSPLIT data is also used in various models describing the atmospheric transport, dispersion and deposition of pollutants and hazardous materials.

The model calculation method is a hybrid between the Lagrangian approach, which uses a moving frame of reference to calculate advection and diffusion (where trajectories or air masses move from their original location), and the Euler method, which uses a fixed three-dimensional grid as a frame of reference for calculating the concentrations of pollutants in the air. HYSPLIT has been developing for more than 30 years, starting with the assessment of simplified single trajectories based on radiosonde observations and ending with a system for accounting for multiple interacting pollutants transported, dispersed and deposited on a local and global scale [20].

\section{Results}

The data on fires acquired by FIRMS stored on the EOSDIS platform are different: the data from the VIIRS satellite probe is supplemented with information on fires detected using the MODIS algorithm due to the higher spatial resolution (375 m), which provides a better response from fires in relatively small areas [3]. 
In order to carry out a statistical analysis of thermal anomalies for the Black Sea region, the area under study was distinguished in the FIRMS system and the period of the highest fire activity for 2018 and 2019 (from June to September 2019) was determined. The qualitative and quantitative results of fire assessment for this period are presented below. According to MODIS data, the number of ignition points turned out to be 3-5 times less than according to VIIRS data (Fig. 1, a).

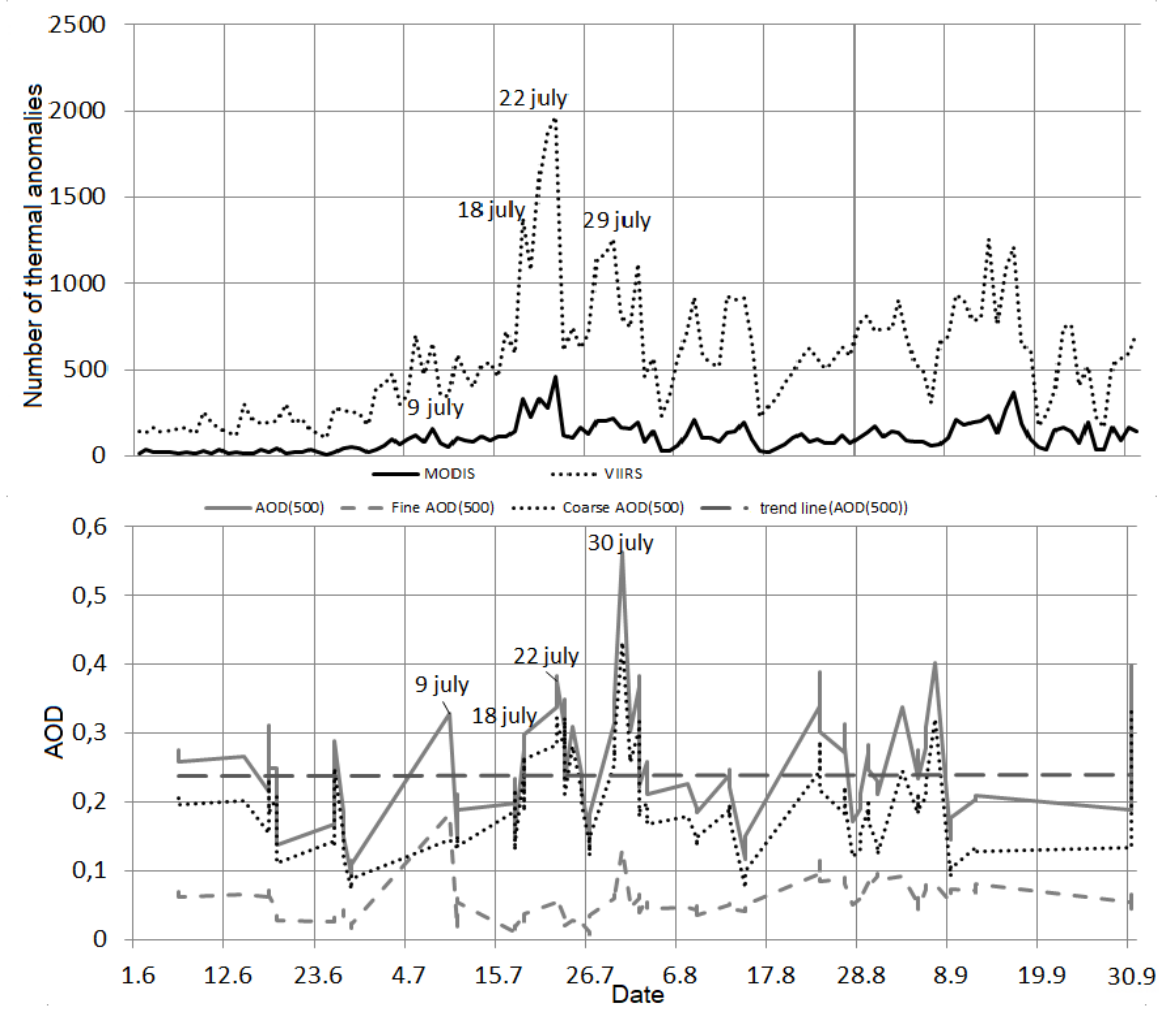

F i g. 1. Number of fires in 2019 based on the MODIS and VIIRS satellite data (a), AOD temporal variability based on in situ measurements by $S P M(b)$

For a comprehensive analysis of the variability of atmospheric aerosol optical characteristics on the days with fires that are anomalous in intensity and in the number of ignition points near the Black Sea, the temporal variability of data obtained from VIIRS and MODIS satellites and field data of SPM photometer (aerosol optical depth) (AOD), as well as the contribution of coarse (Coarse AOD (500)) and fine (Fine AOD (500)) fractions to the total AOD distribution) (Fig. 1), was studied. In 2019, the period with the largest number of fires is the second half of July: according to MODIS data, the number of ignition points was 4707, and according to VIIRS data - 24108. In this period, the maximum (more than five times) discrepancy in the number of thermal anomalies according to the data from two satellites (Fig. 1, a) was also noted. As can be seen from the figure, on July 22, 2019, the maximum number and intensity of thermally active points was observed. On this day, AOD obtained by measuring with SPM photometer (0.36) exceeded the monthly average value $(0.25)$ by 1.5 times. 
For the period of fires, the largest in terms of the number and intensity of ignition points, on the graph of AOD time distribution its maximum value was recorded on July 30 (Fig. $1, b$ ). AOD values for this day at the neighboring Black Sea stations exceed the monthly average values for July by 1.5-2 times: at Galata_Platform AOD station (500) $=0.36$ (with the monthly average AOD (500) $=0.2$ ), at Gloria AOD station (500) $=0.34$ (with the monthly average AOD (500) $=0.265$ ), at Eforie station AOD (500) $=0.423$ (with the monthly average AOD $(500)=0.2$ ). An assessment of the intensity and number of fires for July 30 did not show the maximum value of any of these parameters; however, for the previous day (July 29, 2019), the number of thermal anomalies (1472) exceeded the monthly average (930) by more than 1.5 times. Since no extrema of either optical characteristics or the number of fires were recorded on July 30, 2019, a comprehensive analysis of the variability of the main optical characteristics for 2019, combined with the study of satellite images and air mass transfers, was carried out on July 22, 2019, when abnormally high AOD values, and maximum indicators of the intensity and number of fires (Fig. 1).

For the days with AOD maxima (according to measurements with SPM photometer) (Fig. 1, b), a comparative analysis of these values with the AOD maxima at a wavelength of $532 \mathrm{~nm}$ obtained using CALIPSO ALay-Standard-V4 algorithm was carried out. For these days, the maxima of the lidar ratios $S a$, calculated by the formula $S a=\sigma / \beta$, where $\sigma$ is the extinction coefficient and $\beta$ is the value of the phase scattering function at $180^{\circ}$ (table), were also analyzed.

According to CALIPSO classification of various types of aerosols, smog includes aerosols the lidar coefficients of which at a wavelength of $532 \mathrm{~nm}$ have values within $70 \pm 16$, and at a wavelength of $1064 \mathrm{~nm}-30 \pm 14$. Analysis of the data presented in the table showed that on the days with high (according to the SPM photometer measurements) AOD values, CALIPSO algorithm revealed the presence of smog over the Black Sea region.

An increase in AOD may be due to the appearance of absorbing particles in the atmosphere, which are dust and smoke [19-21]. In order to determine the presence and direction of the absorbing aerosol transport over the Black Sea region on July 22, 2019, the data of HYSPLIT model reverse trajectories were analyzed (Fig. 2).

Values of AOD (based on the SPM data) and lidar relations Sa_532 and Sa_1064 (calculated by the CALIPSO algorithm) on the days when the numbers of thermal anomalies were maximal

\begin{tabular}{c|c|c|c}
\hline Date & AOD (532) & Sa_532 & Sa_1064 \\
\hline 09.07 .2019 & 0.24 & 70 & 44 \\
18.07 .2019 & 0.67 & 70 & 48 \\
22.07 .2019 & 0.78 & 70 & 48 \\
30.07 .2019 & 0.52 & 70 & 44 \\
\hline
\end{tabular}


NOAA HYSPLIT MODEL

Backward trajectories ending at 0600 UTC 22 Jul 19

GDAS Meteorological Data

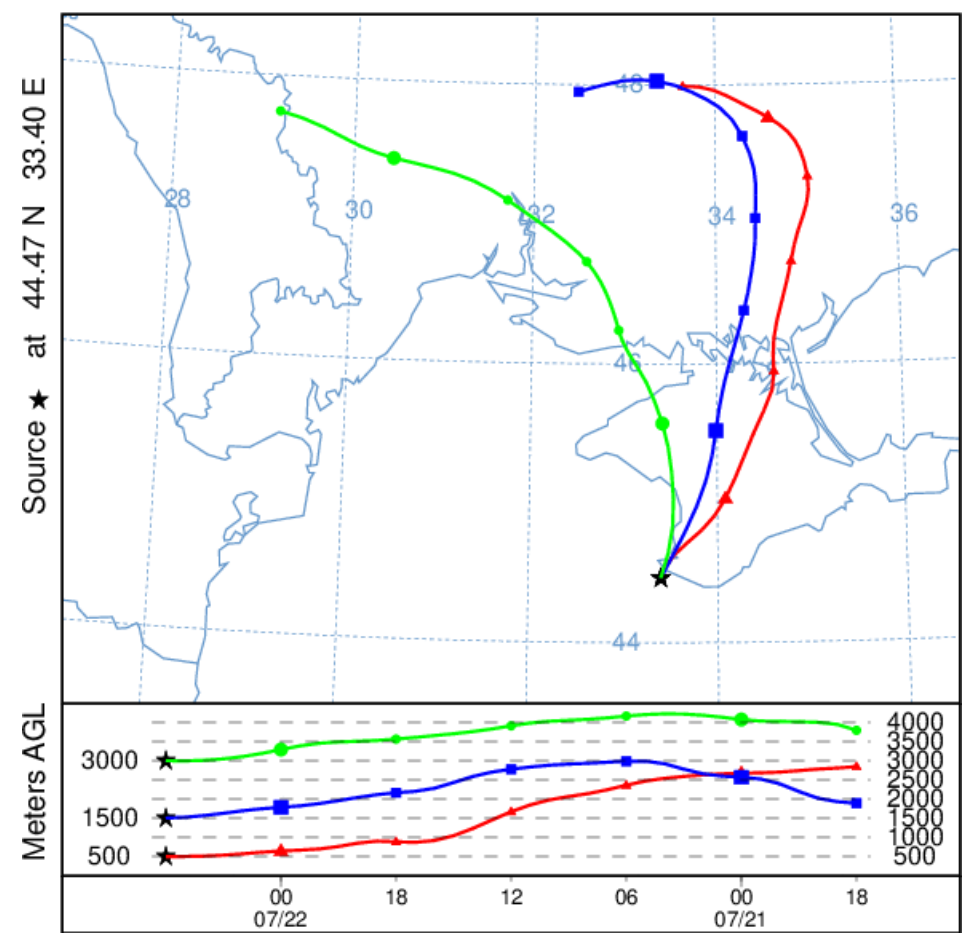

F i g. 2. Back trajectories based on the results of HYSPLIT modeling for 22.07.2019

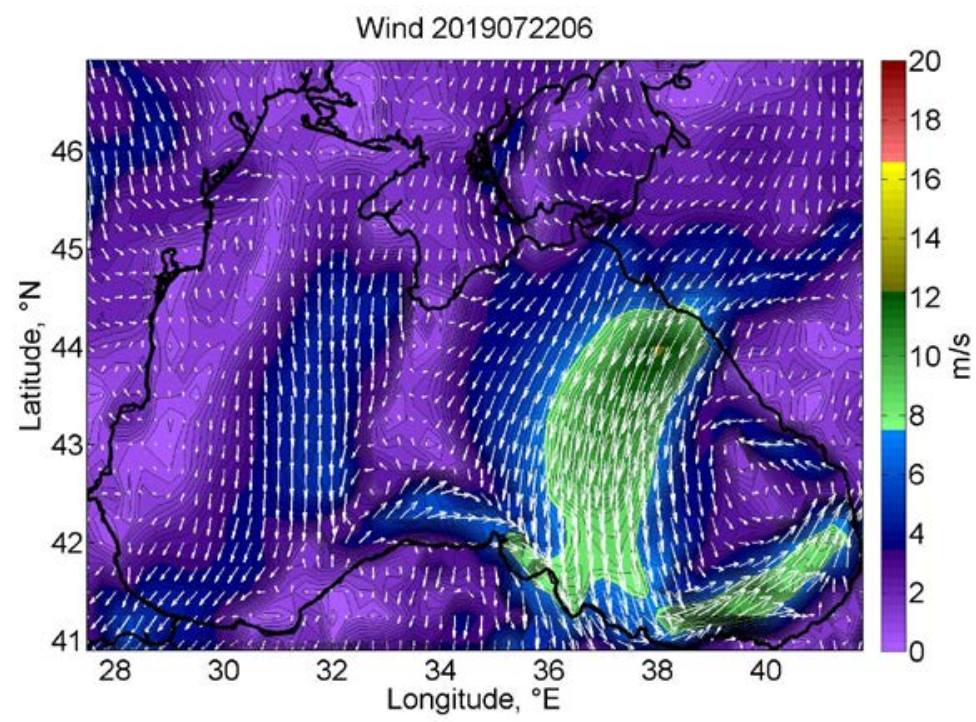

F i g. 3. Wind speed and direction in the atmosphere surface layers on 22.07.2019 
North-western, western and south-western winds, associated with atmospheric circulation in the temperate latitudes of the Northern Hemisphere, prevail over the Black Sea region. An analysis of wind directions and back trajectories showed an atypical for the Black Sea region aerosol transport from the north and northeast to the studied region in the surface layers up to $1.5 \mathrm{~km}$ (Fig. 2, 3).

For a comprehensive analysis of the aerosol sources transported from the north and capable of affecting the optical characteristics of the aerosol over the Black Sea region, the fire maps presented in the public domain on EOSDIS platform (coordinates of thermal anomalies) were analyzed. The analysis of FRP data set for July 22, 2019 revealed the area of fires between Zaporozhye and Donetsk regions (Fig. 4).

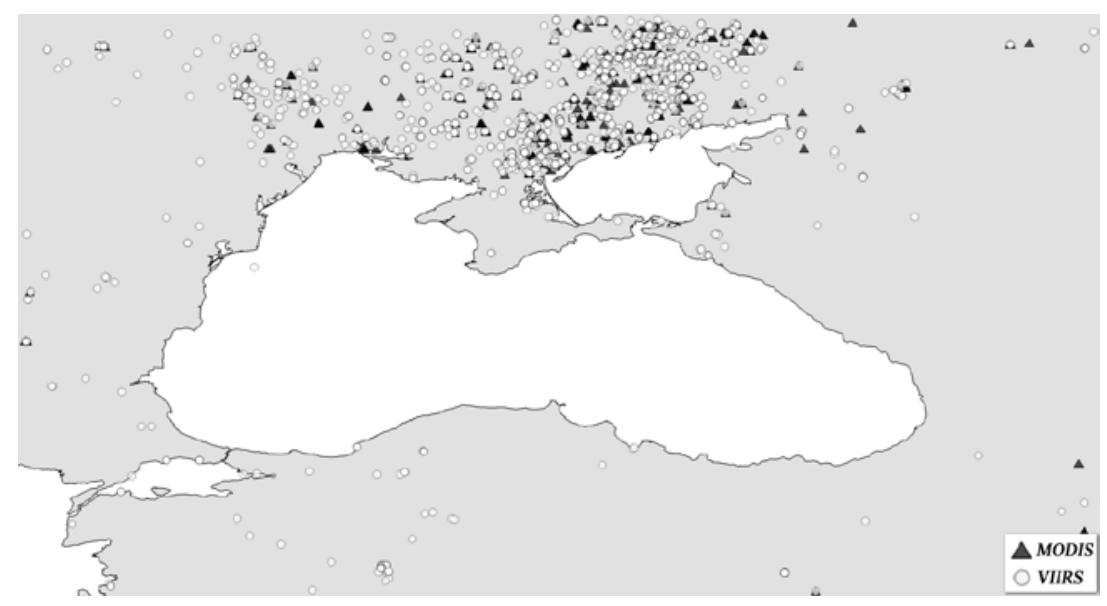

F i g. 4. Distribution of the inflammation points based on the satellite data for July 22, 2019

Soot is a byproduct of biomass combustion and it absorbs a noticeable fraction of the incident solar radiation, which means that it also affects the atmosphere AOD value over the studied region. In order to assess the extent of the spread of fires and soot aerosol, the data of the main optical characteristics and back trajectories of air mass transfer were analyzed both for Sevastopol and for the neighboring western Black Sea AERONET stations: Galata_Platform (Bulgaria), Eforie and Gloria (Romania). Analysis of the data for the same day did not show abnormally high AOD values (500) at any western station; however, on the next day (July 23, 2019), AOD data at all these stations exceeded the monthly average values for July by 1.5-2 times: at Galata_Platform AOD station $(500)=0.42$ (with a monthly average AOD (500) $=0.2$ ), at Gloria AOD station $(500)=0.435$ (with an average monthly AOD $(500)=0.265$ ), at Eforie AOD station $(500)=0.3$ (with an average monthly AOD (500) $=0.2$ ). The maximum AOD 532 value according to CALIPSO data, equal to 0.78, was obtained on July 22, 2019, which coincides with the date of extremely high AOD values both according to $S P M$ measurements and according to the data of the Black Sea stations of $A E R O N E T$ network. In order to confirm the fact that it is the aerosol formed as a result of biomass combustion that is the cause of high AOD values (500) for July 22, 2019, the CALIPSO data on the types of aerosols over the Black Sea region were analyzed (Fig. 5). 


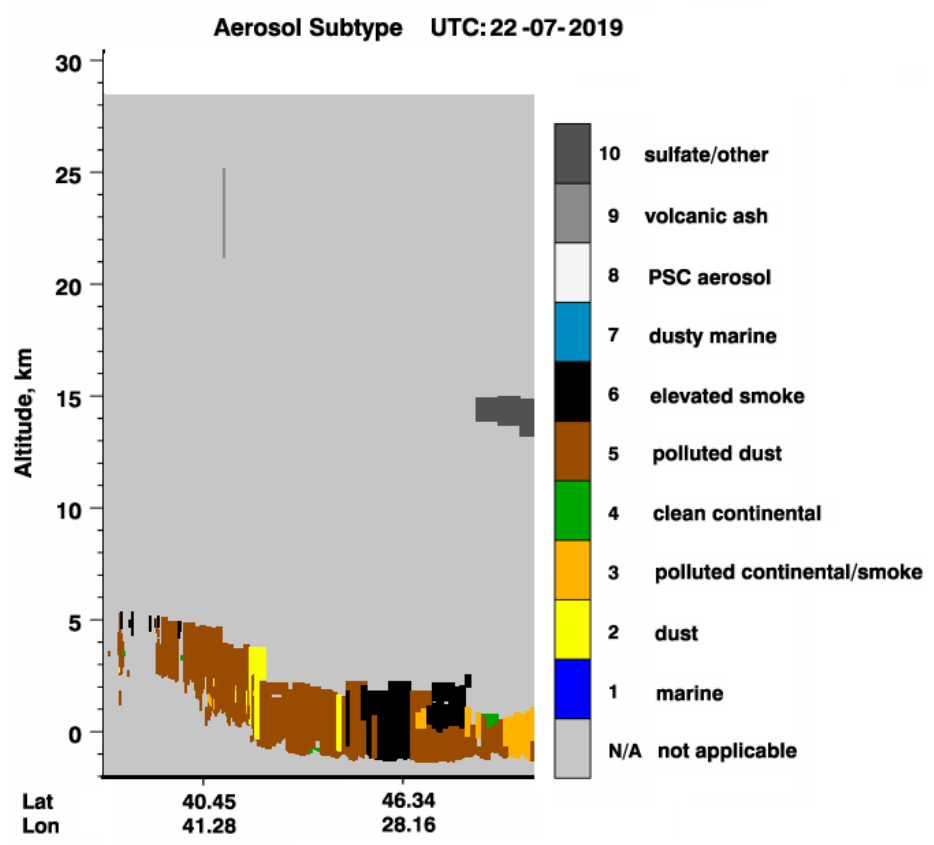

F i g. 5. Aerosol typing based on the CALIPSO satellite data for 22.07.2019

As can be seen from Fig. 5, contaminated dust and smoke are the predominant types of aerosol for the day under study. This is due to the increased values of lidar ratios characteristic of smog, $S a(532)=70$ and $S a(1064)=48$. Since July 22, 2019, the dust transport from both the Sahara and the Syrian Desert, according to satellite data, was not recorded, it can be concluded that the increase in the AOD (500) values was due to the transfer from the north to the Black Sea region of precisely the aerosol formed as a result of the biomass combustion.

\section{Conclusion}

For the cases of registering fires in the Black Sea region using MODIS and VIIRS satellite data, a comprehensive analysis of the data on air mass transfers by HYSPLIT model and CALIPSO satellite data on aerosol types was carried out in order to identify the degree of biomass combustion impact on the atmosphere over the Black Sea region. Analysis of the variability of the main optical characteristics from 2018 to 2019 over the Black Sea according to AERONET network and according to SPM photometer for the dates of intense fires in the Black Sea region showed an excess of the aerosol optical depth daily values at $500 \mathrm{~nm}$ wavelength (AOD (500)) over the monthly mean values by 1.5-2 times. The date of the most intense fires in 2019 is July 22.

Investigation of aerosol transport possible source for this day using the data from two satellites MODIS and VIIRS showed that the area of intense fire and smoke is located northeastward of the Black Sea region. According to CALIPSO data, the predominant types of aerosols for the study day are contaminated dust and smoke. Since each type of aerosol is characterized by a certain set of lidar ratios at the wavelengths of 532 (Sa_532) and $1064 \mathrm{~nm}$ (Sa_1064), an analysis of these 
characteristics was carried out for the days of intense fires during the study period. For July 22, 2019, increased values of lidar ratios characteristic of smog were obtained: $S a \_532=70$ and $S a \_1064=48$. As, according to the satellite data, dust transport from both the Sahara and the Syrian Deserts was not recorded, we can conclude that the increase in AOD values (500) was due to the transfer from the north to the Black Sea region of the aerosol formed as a result of biomass combustion.

\section{REFERENCES}

1. Rahimov, R.F., Kozlov, V.S., Panchenko, M.V., Tumakov, A.G. and Shmargunov, V.P., 2014. Properties of Atmospheric Aerosol in the Plumes of Forest Fires according to the spectronephelometric measurements. Optika Atmosfery i Okeana, 27(02), pp. 126-133 (in Russian).

2. Kalinskaya, D.V. and Suslin, V.V., 2015. Variability of Aerosol Optical Characteristics Atmosphere over the Black Sea during the 2010 Year Summer Fires. In: IO RAS, 2015. Current Problems in Optical of Naturals Waters (ONW'2015). Moscow: IO RAS. Vol. 8, pp. 215-219 (in Russian).

3. Kalinskaya, D.V. and Ryabokon', D.A., 2019. A Study of Aerosol Characteristics over the Black Sea by the FIRMS System during Forest Fires in 2007-2018. Sovremennye Problemy Distantsionnogo Zondirovaniya Zemli iz Kosmosa, 16(4), pp. 247-255 (in Russian).

4. Kondratyev, K.Ya. and Grigoryev, Al.A., 2004. Forest Fires as a Component of Natural Ecodynamics. Atmospheric and Oceanic Optics, 17(4), pp. 245-255.

5. Bondur, V.G., Gordo, K.A. and Kladov, V.L., 2016. [Temporal-Spatial Distributions of Natural Fires Areas and Emissions of Carbon-Containing Gases and Aerosols in the Territory of Northern Eurasia According to Space Monitoring Data]. Issledovanie Zemli iz Kosmosa, (6), pp. 3-20. doi:10.7868/S0205961416060105 (in Russian).

6. Panov, A.V., Prokushkin, A.S., Bryukhanov, A.V., Korets, M.A., Ponomarev, E.I., Sidenko, N.V., Zrazhevskaya, G.K., Timokhina, A.V. and Andreae, M.O., 2018. A Complex Approach for the Estimation of Carbonaceous Emissions from Wildfires in Siberia. Meteorologiya i Gidrologiya, (5), pp. 30-38 (in Russian).

7. Savorskiy, V.P., 2004. [A Node of Distributed Satellite Data System (TSOKHKI) FIRE RAS]. Sovremennnye Problemy Distantsionnogo Zondirovaniya Zemli iz Kosmosa, 1(1), pp. 241-247 (in Russian).

8. Justice, C.O., Giglio, L., Korontzi, S., Owens, J., Morisette, J.T., Roy, D., Descloitres, J., Alleaume, S., Petitcolin, F. and Kaufman, Y., 2002. The MODIS Fire Products. Remote Sensing of Environment, 83(1-2), pp. 244-262. https://doi.org/10.1016/S0034-4257(02)000767

9. $\quad$ Chen, Y., Velicogna, I., Famiglietti, J.S. and Randerson, J.T., 2013. Satellite Observations of Terrestrial Water Storage Provide Early Warning Information about Drought and Fire Season Severity in the Amazon. Journal of Geophysical Research: Biogeosciences, 118(2), pp. 495504. doi:10.1002/jgrg.20046

10. Chu, D.A., Kaufman, Y.J., Ichoku, C., Remer, L.A., Tanre, D. and Holben, B.N., 2002.Validation of MODIS Aerosol Optical Depth Retrieval over Land. Geophysical Research Letters, 29(12), pp. MOD2-1-MOD2-4. doi:10.1029/2001GL013205

11. Ichoku, C., Ellison, L.T., Yue, Y., Wang, J. and Kaiser, J.W., 2016. Fire and Smoke Remote Sensing and Modeling Uncertainties: Case Studies in Northern Sub-Saharan Africa. In: K. Riley, P. Webley and M. Thompson, eds., 2016. Natural Hazard Uncertainty Assessment: Modeling and Decision Support. Washington: AGU, pp. 215-230. doi:10.1002/9781119028116.ch14

12. Panchenko, M.V., Zhuravleva, T.B., Terpugova, S.A., Polkin, V.V. and Kozlov, V.S., 2012. An Empirical Model of Optical and Radiative Characteristics of the Tropospheric Aerosol over West Siberia in Summer. Atmospheric Measurement Techniques, 5(7) pp. 1513-1527. https://doi.org/10.5194/amt-5-1513-2012 
13. Chuvieco, E., Giglio, L. and Justice, C., 2008. Global Characterization of Fire Activity: toward Defining Fire Regimes from Earth Observation Data. Global Change Biology, 14(7), pp. 1488-1502. https://doi.org/10.1111/j.1365-2486.2008.01585.x

14. Glasius, M., la Cour, A. and Lohse, C., 2011. Fossil and Nonfossil Carbon in Fine Particulate Matter: A Study of Five European Cities. Journal of Geophysical Researches: Atmospheres, 116(D11), D11302. https://doi.org/10.1029/2011JD015646

15. Wooster, M.J., Roberts, G., Perry, G.L.W. and Kaufman, Y.J., 2005. Retrieval of Biomass Combustion Rates and Totals from Fire Radiative Power Observations: FRP Derivation and Calibration Relationships between Biomass Consumption and Fire Radiative Energy Release. Journal of Geophysical Research: Atmospheres, 110(D24), D24311. doi:10.1029/2005JD006318

16. Omar, A.H., Winker, D.M., Vaughan, M.A., Hu., Y., Trepte, C.R., Ferrare, R.A., Lee, K-P., Hostetler, C.A., Kittaka, C. [et al.], 2009. The CALIPSO Automated Aerosol Classification and Lidar Ratio Selection Algorithm. Journal of Atmospheric and Oceanic Technology, 26(10), pp. 1994-2014. doi:10.1175/2009JTECHA1231.1

17. Mielonen, T., Arola, A., Komppula, M., Kukkonen, J., Koskinen, J., de Leeuw, G. and Lehtinen, K.E.J., 2009. Comparison of CALIOP Level 2 Aerosol Subtypes to Aerosol Types Derived from AERONET Inversion Data. Geophysical Research Letters, 36(18), L18804. doi:10.1029/2009GL039609

18. Omar, A.H., Won, J-G., Winker, D.M., Yoon, S-C., Dubovik, O. and McCormic, M.P., 2005. Development of Global Aerosol Models Using Cluster Analysis of Aerosol Robotic Network (AERONET) Measurements. Journal of Geophysical Researches: Atmospheres, 110(D10), D10S14. doi:10.1029/2004JD004874

19. Kalinskaya, D.V. and Papkova, A.S., 2017. [Identification of Dust Aerosol over the Black Sea by CALIPSO Radiometer]. In: MHI, 2017. [Seas of Russia: Science, Safety, Resources: Abstracts of Scientific Conference Reports, Sevastopol, 3-7 October 2017]. Sevastopol: MHI, pp. 114-115 (in Russian).

20. Papkova, A.S. and Kalinskaya, D.V., 2017. [Statistic Research of Aerosol Transport over the Black Sea Region in 2016 by the Data of HYSPLIT and AERONET Models]. In: SSU, 2017. Applied Problems of Mathematics: materials of the XXVth international scientific conference. Sevastopol: SSU, pp. 145-148 (in Russian).

21. Kalinskaya, D.V. and Suslin, V.V., 2016. Study Properties of Aerosols over the Black Sea during the Dust Storm of 2015. Ekologicheskaya Bezopasnost' Pribrezhnoy i Shel'fovoy Zon Morya $=$ Ecological Safety of Coastal and Shelf Zones of Sea, (3), pp. 37-43 (in Russian).

About the authors:

Daria V. Kalinskaya - Junior Scientist, Marine Hydrophysical Institute of RAS (2 Kapitanskaya St., 299011, Sevastopol, Russian Federation), Scopus Author ID: 56380591500, kalinskaya@mhi-ras.ru

Anna S. Papkova - Senior Research Engineer, Marine Hydrophysical Institute of RAS (2 Kapitanskaya St., 299011, Sevastopol, Russian Federation), Scopus Author ID: 57203015832, hanna.papkova@gmail.com

Dmitry M. Kabanov - Senior Research Associate, IOA SB RAS (1 Academician Zuev Square, 634055, Tomsk, Russian Federation), Ph. D. (Phys.-Math.), Scopus Author ID: 6701750016, dkab@iao.ru

Contribution of the co-authors:

Daria V. Kalinskaya - statement of the problem, review of the study area atmospheric aerosol, analysis of modeling results, preparation of the paper

Anna S. Papkova - carrying out numerical experiments, analysis of simulation results

Dmitry M. Kabanov - carrying out the experimental studies of the aerosol optical depth of the atmosphere over the ocean and continent by means of SPM

All the authors have read and approved the final manuscript.

The authors declare that they have no conflict of interest. 